\title{
FORMULASI INSEKTISIDA NABATI MINYAK BUNGKIL MIMBA DENGAN SURFAKTAN DEA
}

\section{BOTANICAL INSECTICIDE FORMULATION OF NEEM CAKE OIL WITH DEA SURFACTANT}

\author{
Yusriah $^{1)^{*}}$, Erliza Hambali, ${ }^{1,3)}$, dan Dadang ${ }^{2,3)}$ \\ ${ }^{1)}$ Program Studi Teknologi Industri Pertanian, Fakultas Teknologi Pertanian, Institut Pertanian Bogor \\ Kampus IPB Darmaga, Bogor 16680, Jawa Barat, Indonesia \\ E-mail: : erliza.h@gmail.com \\ ${ }^{2}$ Departemen Proteksi Tanaman, Fakultas Pertanian, Institut Pertanian Bogor, Indonesia \\ ${ }^{3)}$ Surfactant and Bioenergy Research Center, LPPM-IPB \\ Makalah: Diterima 26 April 2017; Diperbaiki 9 Desember 2017; Disetujui 19 Desember 2017
}

\begin{abstract}
Neem cake oil has an active compound in form 242.2 ppm azadirachtin. The active compound has activity as feeding inhibitor, nesting rejection, growing inhibitor and mortality effects of many insect pests. Therefore, neem cake was extracted to produce oil. The purpose of this research was to obtain the best ratio of extraction oil from neem cake by maceration method and oil neem cake formulated by DEA surfactant. The oil extraction from neem cake was undertaken by maceration method using a solvent like $n$-hexane and produce the greatest yield at comparison neem cake and n-hexane 1:4 (w/v). The oil was produced from extraction of neem cake was solid form at room temperature, so it was added a general solvent as usually used in the pesticide industry to dissolved. i.e. Solvesso. The concentration of DEA surfactant used in neem cake oil formulation was $8 \%$. The bioinsecticide formulations of this research was $8 \%$ DEA, $15 \%$ for oil neem cake and $15 \%$ for Solvesso in 30 g formulations.
\end{abstract}

Keywords: DEA surfactant, insecticide formulation, maseration method, neem seed oil

\section{ABSTRAK}

Bungkil mimba masih memiliki senyawa aktif berupa azadirakhtin sebesar 242,2 ppm. Senyawa aktif ini memiliki aktivitas penghambatan makan, penolakan peneluran, penghambat pertumbuhan dan efek kematian pada kebanyakan serangga hama. Tujuan penelitian ini untuk mendapatkan perbandingan terbaik dalam ekstraksi minyak dari bungkil mimba dengan metode maserasi dan mendapatkan formulasi insektisida menggunakan minyak bungkil mimba dan surfaktan DEA. Ekstraksi minyak bungkil mimba dengan metode maserasi menggunakan pelarut $n$-heksan menghasilkan rendemen tertinggi pada perbandingan bungkil dengan pelarut $n-$ heksan 1:4 (w/v). Minyak yang diperoleh berbentuk beku pada suhu ruang sehingga perlu ditambahkan pelarut solvesso yang umum digunakan pada industri pestisida untuk melarutkan bahan. Konsentrasi surfaktan DEA terbaik yang digunakan pada formula insektisida minyak bungkil biji mimba sebesar $8 \%$.Formula insektisida nabatiyang terbaik mengandung $8 \%$ DEA, $46 \%$ minyak bungkil mimba dan $46 \%$ solvesso.

Kata kunci: surfaktan DEA, formulasi insektisida, metode maserasi, minyak bungkil mimba

\section{PENDAHULUAN}

Upaya peningkatan produksi kedelai sering mengalami berbagai kendala. Banyaknya jenis hama potensial yang dapat menyerang dan menurunkan produktivitas tanaman kedelai merupakan salah satu kendala biotik utama. Di Indonesia telah teridentifikasi 16 dari 100 lebih jenis hama potensial yang dapat menyerang kedelai saat mulai tumbuh sampai menghasilkan polong (Adisarwanto, 2005). Salah satu hama yang menyerang tanaman kedelai dan dapat mengakibatkan gagal panen adalah Spodoptera litura. Fase larva hama ini memakan daun hingga daun menjadi sobek, berlobang dan tampak transparan (Suyanto, 1994). Imago S. litura dewasa meletakkan telur secara berkelompok dibawah permukaan daun, satu kelompok telur mencapai 200-300 butir. Serangan ulat grayak terjadi pada malam hari, sedangkan pada siang hari ulat bersembunyi dalam tanah yang lembab.
Penelitian Hendrival et al. (2013) menunjukkan bahwa $S$. litura mulai dijumpai pada fase pertumbuhan kedelai muda sampai fase pengisian biji dan pemasakan polong, namun kehadiran yang sangat membahayakan terjadi pada fase vegetatif sampai berbunga dan pembentukan polong. Penelitian Meidalima (2014) membuktikan bahwa $90 \%$ S. litura dapat berkembang dengan populasi tinggi pada tanaman kedelai.

Pestisida sintetik umumnya digunakan pada pertanian konvensional untuk mencegah serangan hama dan penyakit tumbuhan (Al-Hasan, 2010), karena harganya murah dan bekerja sangat cepat (Blay, 2000). Pestisida sintetik umumnya diaplikasikan seminggu sekali selama masa tanam di lapangan. Efek yang juga dapat ditimbulkan oleh pestisida sintetik terhadap serangga diantaranya mempengaruhi pertumbuhan, perkembangan, tingkah laku, perkembangbiakan, sistem hormon, sistem pencernaan, serta aktivitas biologis lainnya

*Penulis Korespodensi 
yang dapat berujung pada kematian serangga penggangu tanaman (Kardinan, 2002). Salah satu upayauntuk mengurangi residu pestisida sintetik adalah penggunaan insektisida nabati. Menurut United States Environmental Protection Agency (EPA), insektisida nabati didefinisikan sebagai pestisida yang dibuat dari bahan-bahan tumbuhan.

Berbagai jenis tumbuhan diketahui berpotensi sebagai insektisida nabati karena mengandung senyawa bioaktif antara lain saponin, tanin, alkaloid, alkenil fenol, flavonoid, dan terpenoid. Senyawa sekunder ini merupakan pertahanan tumbuhan terhadap serangan organisme lain. Pengetahuan dan penelitian mengenai pestisida nabati tersebut telah banyak dilakukan di negaranegara maju, misalnya Amerika, Jepang, dan negaranegara Eropa (Rukmana dan Yuyun, 2002). Beberapa tumbuhan diketahui dapat memberi efek mortalitas terhadap serangga, sehingga tumbuhan tersebut dapat digunakan sebagai alternatif insektisida nabati. Salah satunya adalah mimba (Azadirachta indica) yang memiliki senyawa aktif yang banyak terkandung di dalam biji. Kadar zat aktif yang terkandung dalam biji mimba sekitar 0,1 - 0,5\% dari berat biji kering mimba (Sukrasno, 2003).

Insektisida yang beredar secara luas di masyarakat merupakan hasil formulasi yang terdiri dari bahan aktif dan bahan tambahan (adjuvant) Keberadaan bahan tambahan sangat diperlukan karena memilki peranan penting dalam mekanisme kerja bahan aktif. Bahan tambahan yang digunakan dalam formulasi juga dapat menentukan bentuk formulasi insektisida. Adapun bentuk formulasi insektisida diantaranya adalah emulsifiable concentrate (EC), wettable powder (WP), solution concentrate (SL), suspension concentrate (SC), water dispersible granules (WG), granules (GR) dan lain-lain (Knowles, 2008). Penggunaan surfaktan di industri formulasi insektisida sangat dibutuhkan sebagai salah satu bahan tambahan (adjuvant), khususnya untuk formulasi insektisida dengan bentuk Emulsifiable concentrate (EC) (Knowles, 2008).

Penggunaan insektisida nabati umumnya kurang efektif karena formulasinya masih sangat sederhana sehingga diperlukan bahan aditif (tambahan) seperti surfaktan yang memiliki fungsi sebagai pendispersi dan perata bahan aktif sekaligus perekat yang umumnya digunakan pada pestisida sintetik. Suryani et al. (2012) menyatakan bahwa surfaktan dietanolamida memiliki nilai tegangan permukaan yang paling rendah (20,97 dyne/cm) untuk digunakan pada industri insektisida dibandingkan surfaktan yang lain seperti APG (2122 dyne/cm), etoksilat (23-25 dyne/cm), dan lauril betain $(31,17 \mathrm{dyne} / \mathrm{cm})$ sehingga surfaktan DEA sangat berpotensi sebagai bahan aditif untuk meningkatkan efektifitas insektisida. DEA diperoleh melalui proses amidasi. Probowati et al. (2012) melakukan proses amidasi untuk menghasilkan surfaktan DEA menggunakan metil ester dari minyak kelapa murni (VCO) dan dietanolamina pada suhu $160^{\circ} \mathrm{C}$ selama 3 jam dengan katalis $\mathrm{NaOH} 1 \%$. Selain minyak kelapa murni (VCO) sebagai sumber minyak nabati, minyak sawit (CPO) juga dapat menjadi bahan baku surfaktan dietanolamida (DEA) yang potensial karena ketersediaannya yang melimpah di Indonesia.

Penelitian ini bertujuan untuk mengetahui perbandingan terbaik dalam ekstraksi minyak pada bungkil mimba dengan metode maserasi menggunakan $\mathrm{n}$-heksan dan mendapatkan formula insektisida menggunakan minyak bungkil mimba dan surfaktan DEA.

\section{BAHAN DAN METODE}

\section{Tempat Penelitian}

Penelitian dilaksanakan di Laboratorium Pusat Penelitian Surfaktan dan Bioenergi Lembaga Penelitian dan Pengabdian kepada Masyarakat Institut Pertanian Bogor (SBRC-LPPM-IPB), Balai Besar Penelitian Agro Kementerian Perindustrian serta Laboratorium Fisiologi dan Toksikologi Serangga, Faperta IPB.

\section{Alat dan Bahan}

Bahan yang digunakan dalam penelitian ini adalah bungkil biji mimba, surfaktan DEA, minyak bungkil biji mimba, n-heksan dan solvesso-150. Peralatan yang digunakan adalah soxhlet AV-HM04, homogenizer HG-15D, neraca analitik XB 220A, kertas saring, rotary vaccum evaporator, stirrer, pemanas, tensiometer, contact angel dan mikroskop leica.

\section{Analisis Proksimat Bungkil Mimba}

Analisis proksimat bungkil mimba menggunakan metode SNI 01-2891-1992, meliputi kadar abu total, kadar air total, kadar lemak total, kadar protein total dan kadar karbohidrat total.

\section{Ekstraksi Minyak dari Bungkil Biji Mimba}

Biji mimba yang digunakan memiliki kadar air 5\%. Biji dipress menghasilkan minyak dan bungkil. Ekstraksi minyak dari bungkil biji mimba menggunakan metode maserasi menggunakan pelarut n-heksan yang direndam selama 24 jam. Perbandingan serbuk bungkil mimba dengan nheksan yang digunakan adalah 1:2, 1:3, 1:4, dan 1:5 (w/v) yang diulang 2 kali. Untuk mendapatkan minyak, larutan kemudian dipisahkan dari kotoran hasil saringan. Larutan selanjutnya disaring dengan kain saring,kemudian dipisahkan antara pelarut dan minyak dengan menggunakan rotary vaccum evaporator. Minyak yang dihasilkan masih berupa crude oil karena mengandung kotoran sisa bungkil. Minyak kemudian disaring kembali menggunakan kertas saring. Minyak yang dihasilkan kemudian 
dianalisis sifat fisiko kimia dan kadar azadirakhtinnya.

\section{Formulasi Insektisida Nabati}

Penentuan Konsentrasi Surfaktan DEA dalam Minyak Mimba dengan Metode CMC

Analisis critical micelle concentration (CMC) dilakukan dengan mengukur tegangan permukaan atau tegangan antar muka pada surfaktan DEA didalam minyak bungkil biji mimba. Critical micelle concentration surfaktan DEA yang diukur adalah $1 \%$ sampai $10 \%$ dalam minyak bungkil mimba.

\section{Penentuan Rasio Minyak Bungkil Mimba dan Solvesso}

Minyak bungkil mimba yang dihasilkan melalui proses ekstraksi bersifat beku dalam suhu ruang sehingga perlu ditambahkan pelarut agar tetap cair pada suhu ruang. Untuk mengetahui solvesso yang dibutuhkan maka dilakukan uji dengan membandingkan minyak bungkil mimba dengan solvesso. Perbandingan antara solvesso dengan minyak bungkil mimba adalah $0,1: 1$ sampai dengan $1: 1(w / w)$.

\section{Formulasi Insektisida Nabati}

Formulasi insektisida berbahan aktif bungkil biji mimba yang dilakukan mengacu pada metode Packiam et al. (2012). Formulasi yang dilakukan menggunakan surfaktan DEA yang memiliki CMC paling rendah dan ditambahkan solvesso R-150 dalam 30 g minyak bungkil mimba. Kontrol digunakan Solveso R-150 yang ditambahkan $8 \%$ surfaktan DEA. Kemudian di stirrer selama 10 menit. Pembuatan formula diulang sebanyak 3 kali. Formula pestisida yang dihasilkan kemudian dianalisis kemampuan menurunkan tegangan permukaan, ukuran droplet dan sudut kontaknya di Laboratorium Surfaktan SBRC LPPM IPB.

\section{Pengujian Formula Insektisida Mimba Terhadap Larva Spodoptera Litura}

Daun kedelai dan Spodoptera litura yang digunakan berasal dari Laboratorium Fisiologi dan Toksikologi Serangga IPB. Pengujian aktivitas insektisida formula mimba dilakukan dengan menggunakan metode perlakuan pakan (metode celup/residu pada daun) (Dadang dan Prijono, 2008). Formulasi insektisida yang terpilih diencerkan terlebih dahulu dengan akuades untuk mendapatkan sediaan uji 10 dan $50 \mathrm{~mL} / \mathrm{l}$. Daun kedelai dicelupkan dalam sediaan mimba atau sediaan kontrol hingga basah merata lalu dikeringanginkan. Satu helai daun kedelai perlakuan atau daun kontrol dimasukkan ke dalam tabung plastik yang dialasi potongan tissue, lalu larva $S$. litura instar ke-3 dimasukkan ke dalam tabung tersebut. Pengamatan dilakukan pada hari ke2 dan 4 dengan menghitung jumlah larva yang mati.
Daun yang telah mengandung residu insektisida tersebut diberikan ke serangga uji sebagai makanan, dengan demikian bahan aktif insektisida masuk ke dalam tubuh serangga uji melalui oral (dimakan). Kontrol yang digunakan yaitu air dan surfaktan DEA tanpa minyak bungkil biji mimba.

\section{HASIL DAN PEMBAHASAN}

\section{Komponen Proksimat Bungkil Biji Mimba}

Analisis kandungan bahan yang terdapat dalam biji dan bungkil mimba dilakukan melalui analisis proksimat. Bungkil biji mimba sisa pengepresan memiliki kadar protein sebesar 14,70\%, kadar lemak 11,60\% dan kadar karbohidrat sebesar $59,10 \%$. Kadar protein bungkil mimba tersebut cukup tinggi, sehingga dalam ekstraksi minyak, penguraian protein akan menghasilkan senyawasenyawa yang larut dalam minyak dan cenderung mengotori minyak. Keadaan ini menyebabkan warna yang gelap pada minyak yang dihasilkan. Data hasil analisis proksimat minyak dari bungkil biji mimba disajikan pada Tabel 1.

Tabel 1. Data hasil analisis proksimat minyak dari bungkil biji mimba

\begin{tabular}{lc}
\hline \multicolumn{1}{c}{ Parameter } & Jumlah $(\boldsymbol{\%})$ \\
\hline Kadar abu & 8,32 \\
Kadar air & 6,32 \\
Kadar protein & 14,70 \\
Kadar lemak & 11,60 \\
Kadar karbohidrat & 59,10 \\
\hline
\end{tabular}

\section{Ekstraksi Bungkil Mimba dengan Metode Maserasi}

Bungkil mimba hasil pengepresan screw press diekstraksi menggunakan pelarut. Metode ekstraksi bergantung pada polaritas senyawa yang akan diekstrak. Suatu senyawa menunjukkan kelarutan yang berbeda-beda dalam pelarut yang berlainan. Hal-hal yang perlu diperhatikan dalam pemilihan pelarut adalah selektivitas, kemampuan mengekstrak, toksisitas, kemudahan untuk diuapkan, dan harga pelarut. Pada penelitian ini digunakan pelarut n-heksan sebagai salah satu senyawa hidrokarbon yang dapat berkondensasi, mudah didapat, murah serta digunakan secara luas dengan suhu didih $68,7^{\circ} \mathrm{C}$. Selain itu, pelarut yang sesuai untuk gliserida adalah senyawa hidrokarbon rantai lurus karena mempunyai suhu didih rendah. Pelarut merupakan faktor yang sangat mempengaruhi kualitas minyak, sebagian besar tergantung pada pelarut yang dipilih. Houghton dan Raman (1998) menjelaskan bahwa dasar pemilihan pelarut untuk ekstraksi bahan tumbuhan adalah kepolaran suatu molekul. Senyawa yang bersifat polar akan dengan mudah diekstraksi dengan pelarut yang bersifat polar juga sebaliknya senyawa yang bersifat non polar akan mudah diekstraksi dengan pelarut yang bersifat 
non polar, atau dikenal dengan prinsip likes dissolve likes. Rendemen minyak bungkil mimba dengan proses maserasi disajikan pada Tabel 2.

Tabel 2. Rendemen minyak bungkil mimba dengan proses maserasi

\begin{tabular}{cc}
\hline $\begin{array}{c}\text { Perlakuan } \\
\text { \{bungkil mimba dalam n- } \\
\text { heksan (b/v) }\}\end{array}$ & Rendemen (\%) \\
\hline $1: 2$ & $5,61 \pm 0,07$ \\
$1: 3$ & $6,52 \pm 0,40$ \\
$1: 4$ & $\mathbf{7 , 2 8} \pm \mathbf{0 , 4 6}$ \\
$1: 5$ & $6,93 \pm 0,35$ \\
\hline
\end{tabular}

Hasil analisis sidik ragam dari rendemen dengan metode maserasi menunjukkan bahwa $\mathrm{f}$ hitung lebih kecil dari $\mathrm{f}$ tabel $(0,4776<4,35)$. Hal ini menunjukkan bahwa tidak ada beda nyata antara tiap perbandingan yang digunakan, sehingga perbandingan yang diambil adalah rendemen yang menghasilkan jumlah tertinggi yaitu pada perbandingan 1:4 $(7,28 \pm 0,46 \%)$. Rendemen adalah minyak bungkil mimba yang dihasilkan melalui proses maserasi dan sebagai salah satu faktor penting dalam menentukan minyak bungkil mimba yang selanjutnya digunakan dalam formulasi. Maserasi digunakan untuk melarutkan bahan baku yang mengandung zat yang mudah larut dalam pelarut. Keuntungan metode ini adalah pengerjaan dan peralatan yang digunakan sederhana dan mudah diperoleh. Jumlah ekstrak yang diperoleh kemudian dinyatakan sebagai rendemen. Dari metode maserasi yang dilakukan, perbandingan 1:4 menghasilkan jumlah rendemen yang tertinggi sebesar 7,28 $\pm 0,46 \%$ (Tabel 2). Karakter fisik dari minyak yang dihasilkan dari ekstraksi bungkil mimba diketahui berwarna gelap dan mengandung endapan. Hal ini diduga bahwa minyak bungkil mimba hasil pengepresan masih mengandung gum (getah), asam lemak, fosfolipid dan senyawa pengotor lainnya.

\section{Sifat Fisik Minyak dan Kadar Azadirachtin dari Bungkil Biji Mimba}

Analisis ini bertujuan untuk mengetahui karakteristik minyak bungkil biji mimba yang dihasilkan. Hasil analisis sifat fisiko-kimia minyak bungkil biji mimba disajikan pada Tabel 3 . Berdasarkan hasil analisis, minyak bungkil biji mimba memiliki densitas sebesar $0,914 \mathrm{gr} / \mathrm{cm}^{3}$. Densitas merupakan salah satu parameter penting yang perlu diujikan pada produk formula insektisida nabati dari minyak bungkil mimba. Densitas adalah nilai yang diperoleh sebagai hasil pembagian antara satuan massa per volume $(\mathrm{m} / \mathrm{v})$.

Viskositas merupakan gaya gesekan antara molekul-molekul yang menyusun suatu fluida. Pada zat cair, viskositas disebabkan karena adanya gaya kohesi (gaya tarik menarik antara molekul sejenis). Viskositas menentukan kemudahan suatu molekul bergerak karena adanya gesekan antar lapisan material. Karenanya viskositas menunjukkan tingkat ketahanan suatu cairan untuk mengalir. Semakin besar viskositas maka aliran semakin lambat. Besarnya viskositas dipengaruhi oleh beberapa faktor seperti temperatur, gaya tarik antar molekul dan ukuran serta jumlah molekul terlarut. Viskositas minyak bungkil biji mimba mencapai $29,5 \mathrm{cP}$ pada suhu $45^{\circ} \mathrm{C}$. Sebagai perbandingan, air pada suhu $25^{\circ} \mathrm{C}$ memiliki viskositas $0,89 \mathrm{cP}$ dan olive oil sebesar $81 \mathrm{cP}$.

Azadirakhtin merupakan senyawa dari metabolit sekunder yang dihasilkan oleh tumbuhan. Schoonhoven (2005) menyatakan bahwa senyawa dari metabolit sekunder berperan dalam sistem pertahanan tanaman terhadap serangga dan organisme pengganggu tanaman (OPT) lainnya. Terpenoid merupakan kelompok terbesar dari metabolit sekunder. Contoh yang paling terkenal adalah penghambat makan dari golongan terpenoid yaitu azadirakhtin yang telah diformulasi secara komersial (Schumutterer, 1990). Hal ini juga diperkuat oleh Athanassiou et al. (2005) dan Kavallieratos et al. (2007) bahwa azadirakhtin juga memiliki kemampuan sebagai sterilisasi dan pengatur pertumbuhan serangga untuk mengendalikan berbagai hama pertanian. Kadar azadirakhtin pada minyak bungkil biji mimba yaitu sebesar 242,2 ppm. Kadar azadirakhtin yang dihasilkan lebih rendah dibandingkan dengan kadar azadirakhtin yang ada pada minyak biji mimba. Hal ini disebabkan oleh minyak yang didapatkan dari bungkil biji mimba merupakan sisa pengepresan biji mimba yang telah dikeringanginkan.

Tabel 3. Sifat fisik dan kinerja minyak bungkil biji mimba dan kadar azadirakhtin

\begin{tabular}{lcc}
\hline \multicolumn{1}{c}{ Parameter* } & Nilai & Satuan \\
\hline Densitas & 0,914 & $\mathrm{~g} / \mathrm{cm}^{3}$ \\
Viskositas & 29,5 & $\mathrm{cP}$ \\
Kadar azadirakhtin minyak & 242,2 & $\mathrm{ppm}$ \\
bungkil biji mimba & & \\
*ket. diukur pada suhu $45^{\circ} \mathrm{C}$ & &
\end{tabular}

\section{Formulasi Insektisida Nabati dengan Surfaktan DEA}

Konsentrasi Surfaktan DEA pada Minyak Bungkil Mimba

Penentuan konsentrasi surfaktan bertujuan untuk menentukan konsentrasi maksimum surfaktan yang akan digunakan dalam formulasi. Metode yang digunakan adalah CMC (critical micelle concentration), dimana cara menentukan konsentrasinya adalah dengan mengukur tegangan permukaan larutan surfaktan dengan berbagai konsentrasi yaitu $1-10 \%$.

Sifat utama surfaktan adalah sebagai bahan aktif permukaan (Probowati et al., 2012). Gaya tarik permukaan suatu fluida terhadap udara akan menjadi lebih rendah karena adanya pengaruh senyawa surfaktan. Setelah mencapai konsentrasi tertentu, 
tegangan permukaan akan konstan walaupun konsentrasi surfaktan ditingkatkan. Bila surfaktan ditambahkan melebihi konsentrasi ini maka surfaktan mengagregasi membentuk misel. Konsentrasi terbentuknya misel ini disebut CMC. Tegangan permukaan akan menurun hingga $\mathrm{CMC}$ tercapai. Setelah CMC tercapai, tegangan permukaan akan konstan menunjukkan bahwa antarmuka menjadi jenuh dan terbentuk misel yang berada dalam keseimbangan dinamis dengan monomernya.

Berdasarkan analisis tegangan permukaan, penambahan surfaktan DEA hasil penelitian mampu menurunkan tegangan permukaan minyak bungkil biji mimba hingga 28,1 dyne/cm pada konsentrasi $8 \%$. Hal ini sesuai dengan pengamatan Charlena et al. (2009), bahwa nilai tegangan permukaan untuk larutan yang ditambahkan surfaktan akan terus menurun sebelum larutan tersebut mencapai titik CMC, setelah nilai CMC mencapai titik minimum (titik jenuh), maka selanjutnya hanya sedikit terjadi perubahan pada nilai tegangan permukaan. Minyak bungkil mimba bersifat padat sehingga perlu ditambahkan pelarut sehingga cair dalam suhu ruang.

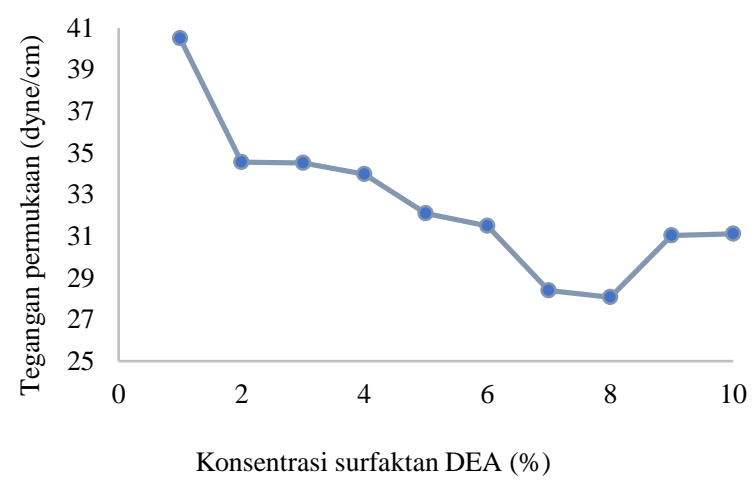

Gambar 1. Konsentrasi surfaktan DEA dalam minyak bungkil biji mimba

\section{Rasio Minyak Bungkil Mimba dan Solvesso}

Minyak bungkil mimba yang dihasilkan melalui ekstrasi maserasi berbentuk padat sehingga perlu ditambahkan pelarut agar dapat cair di suhu ruang. Pelarut yang dipilih adalah solvesso. Pemanfaatan pelarut solvesso pada berbagai industri digunakan salah satunya untuk formulasi pestisida. Solvesso mempunyai tingkat toksisitas yang rendah dan bersifat degredabel atau mudah terdegradasi (MSDS, 2012). Kelarutan minyak bungkil mimba dan solvesso pada berbagai perbandingan disajikan pada Tabel 4.

Perbandingan solvesso dan minyak bungkil mimba yang diujicobakan adalah 0,1:1 sampai dengan 1:1 (w/w). Perbandingan yang digunakan adalah 1:1 (w/w) sebab minyak bungkil mimba dapat cair pada suhu ruang.

Tabel 4. Kelarutan minyak bungkil mimba dan solvesso

\begin{tabular}{ccc}
\hline $\begin{array}{c}\text { Minyak } \\
\text { bungkil } \\
\text { mimba }(\mathbf{g})\end{array}$ & $\begin{array}{c}\text { Solvesso } \\
(\mathbf{g})\end{array}$ & $\begin{array}{c}\text { Pengamatan visual } \\
\text { pada suhu ruang }\end{array}$ \\
\hline 1 & 0,1 & Tidak larut \\
1 & 0,2 & Tidak larut \\
1 & 0,3 & Tidak larut \\
1 & 0,4 & Tidak larut \\
1 & 0,5 & Tidak larut \\
1 & 0,6 & Tidak larut \\
1 & 0,7 & Tidak larut \\
1 & 0,8 & Tidak larut \\
1 & 0,9 & Tidak larut \\
$\mathbf{1}$ & $\mathbf{1}$ & Larut \\
\hline
\end{tabular}

\section{Sifat Fisik Insektisida Nabati}

Untuk mengetahui kemampuan insektisida larutan formula minyak mimba maka diuji dengan mengukur tegangan permukaan, sudut kontak dan analisa droplet. Surfaktan memiliki kemampuan untuk menurunkan tegangan permukaan suatu cairan. Nilai tegangan permukaan yang rendah menunjukkan gaya tarik antar partikel yang rendah pada permukaan suatu larutan. Hal tersebut menjadi sebuah nilai lebih pada formulasi khususnya untuk produk insektisida. Tegangan permukaan yang rendah dari larutan insektisida dapat menurunkan sudut kontak insektisida pada permukaan daun, sehingga meningkatkan penyebaran area semprot insektisida (Yang et al., 2013). Tegangan permukaan formula dengan minyak bungkil mimba sebesar $38,85 \pm 0,64$ dyne/cm, sedangkan nilai tegangan permukaan pada kontrol adalah 37,50 $\pm 0,57$ dyne/cm (Tabel 5).

Analisa sudut kontak dilakukan untuk mengetahui besaran atau nilai sudut kontak antara formulasi yang telah diencerkan hingga 1\% pada permukaan daun kedelai. Analisis ini berguna untuk mengetahui kemampuan surfaktan DEA dalam menyebarkan minyak mimba pada permukaan daun kedelai.

Tabel 5. Sifat fisik pada formula insektisida nabati

\begin{tabular}{lccc}
\hline \multicolumn{1}{c}{ Perlakuan } & Kontrol* & $\begin{array}{c}\text { Larutan } \\
\text { formulasi* }\end{array}$ & Satuan \\
\hline Tegangan permukaan & $37,50 \pm 0,57$ & $38,85 \pm 0,64$ & dyne/cm \\
Sudut kontak** & 0 & $12,74 \pm 0,37$ & $\mathrm{o}$ \\
Ukuran droplet & $3,22 \pm 0,35$ & $4,36 \pm 0,18$ & $\mu \mathrm{m}$ \\
\hline * Diukur pada suhu $45^{\circ} \mathrm{C}$ & & & \\
**Sudut kontak setelah 10 menit & & &
\end{tabular}


Masing-masing sampel dianalisa sebanyak 2 kali ulangan dengan melihat sudut kontak saat tetesan pertama ( 0 menit) dan sudut kontak setelah 10 menit. Sudut kontak pada formula minyak bungkil mimba setelah 10 menit yaitu $12,74 \pm 0,37^{\circ}$. Adanya penambahan solvesso pada formula minyak bungkil mimba menjadikan formula lebih encer dan cepat menyerap pada daun kedelai, sedangkan nilai sudut kontak pada kontrol adalah $0^{\circ}$.

Analisis droplet dilakukan untuk mengetahui ukuran droplet emulsi yang terbentuk oleh campuran minyak nimba dengan surfaktan DEA yang diencerkan dengan air hingga konsentrasi formulanya menjadi $1 \%$. Pengamatan ukuran droplet dilakukan menggunakan mikroskop pada perbesaran $1000 \mathrm{x}$ (seribu kali). Hal tersebut dimaksudkan untuk memastikan sistem emulsi produk insektisida minyak bungkil mimba berukuran mikro. Pada sistem emulsi, droplet berukuran lebih dari $0,1 \mu \mathrm{m}$ atau 0,1-50 $\mu \mathrm{m}$ berbentuk butiran yang terdispersi dengan baik terhadap cairan lainnya. Semakin kecil ukuran droplet menunjukkan sifat emulsi yang baik (deMan, 1997). Ukuran droplet pada larutan formulasi minyak bungkil mimba yaitu $4,36 \pm 0,18 \mu \mathrm{m}$, sedangkan ukuran droplet pada kontrol adalah $3,22 \pm 0,35 \mu \mathrm{m}$.

\section{Hasil Uji Aplikasi Formula Insektisida Nabati}

Kematian serangga uji pada perlakuan dengan formulasi bungkil mimba pada konsentrasi pengenceran 10 dan $50 \mathrm{~mL} / 1$ secara umum tidak meningkat nyata pada 2 dan 4 hari setelah perlakuan (HSP). Perlakuan pada $10 \mathrm{~mL} / 1$ mengakibatkan kematian serangga uji $2 \%$ pada 2 HSP dan $4,2 \%$ pada $4 \mathrm{HSP}$, sedangkan pada perlakuan konsentrasi $50 \mathrm{~mL} / \mathrm{l}$ serangga uji mengalami kematian sebesar $12,2 \%$ pada 2 HSP dan 12,5\% pada 4 HSP (Tabel 6). Kematian serangga uji pada konsentrasi 10 dan 50 $\mathrm{mL} / \mathrm{l}$ tidak cukup signifikan dibandingkan kemampuan Spodoptera litura sebagai hama tanaman.

Daun yang dicelup sediaan kontrol lebih cepat mengering dan menghitam dibandingkan dengan daun yang dicelup sediaan bungkil mimba 10 dan $50 \mathrm{~mL} / \mathrm{l}$. Hal tersebut menandakan terjadinya kematian jaringan daun (nekrosis) sehingga bagian daun kontrol yang mati mudah ditumbuhi cendawan. Pada pengamatan 48 JSP, daun kontrol yang sudah berwarna kehitaman tampak ditumbuhi miselium cendawan yang berwarna putih. Diduga bahwa sifat fitotoksik sediaan kontrol tersebut tampaknya disebabkan oleh tingginya kandungan pelarut Solvesso R-150.

Hasil uji pada Tabel 6 menunjukkan banyaknya daun kedelai perlakuan yang dimakan larva $S$. litura tidak sebanding dengan banyaknya daun kontrol yang dimakan. Selain itu, ukuran dan kondisi larva perlakuan sebanding dengan larva kontrol sehingga dapat dikemukakan bahwa sediaan formulasi bungkil mimba sampai konsentrasi 50 $\mathrm{mL} / \mathrm{l}$ tidak efektif terhadap larva $S$. litura. Uji mortalitas pada formulasi insektisida nabati menggunakan minyak bungkil mimba kurang efektif. Hal ini diduga bahwa masih banyak gum dan senyawa pengotor lainnya pada minyak bungkil mimba sehingga perlu untuk dimurnikan.
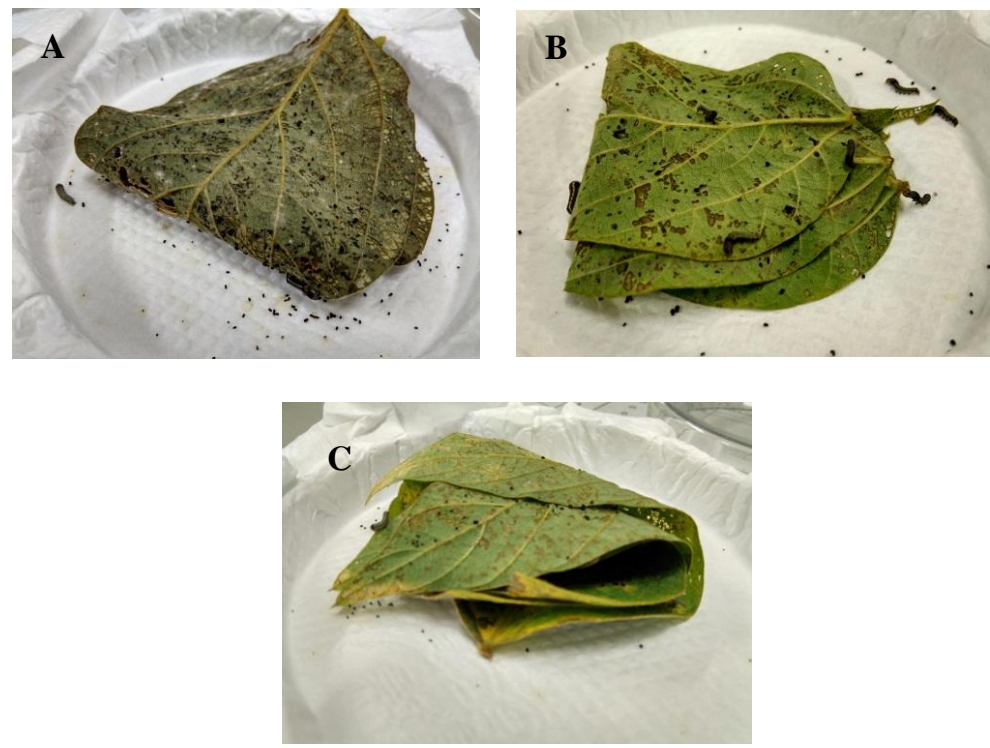

Gambar 8. Keadaan daun kedelai pada 2 hari setelah perlakuan (HSP) dengan sediaan bungkil mimba. A: kontrol, B: $10 \mathrm{~mL} / 1, \mathrm{C}$ : $50 \mathrm{~mL} / \mathrm{l}$. Sediaan kontrol merusak daun sehingga pada 2 HSP daun tampak menghitam yang mencerminkan kerusakan jaringan daun (nekrosis). 
Tabel 6. Mortalitas larva S. litura pada perlakuan formulasi bungkil mimba

\begin{tabular}{lcc}
\hline \multirow{2}{*}{$\begin{array}{c}\text { Konsentrasi } \\
(\mathbf{m} / \mathbf{L})\end{array}$} & \multicolumn{2}{c}{$\begin{array}{c}\text { Mortalitas (\%) pada n hari } \\
\text { setelah perlakuan }(\mathbf{n})^{\mathbf{a}}\end{array}$} \\
\cline { 2 - 3 } \multicolumn{1}{c}{} & $\mathbf{2}$ & $\mathbf{4}$ \\
\hline Kontrol $^{\mathrm{b}}$ & 0 & 0 \\
10 & 2,0 & 4,2 \\
50 & 12,2 & 12,5 \\
\hline
\end{tabular}

Keterangan:

${ }^{\mathrm{a}} \mathrm{n}=$ jumlah serangga uji pada awal pengujian, yaitu 50 larva instar III dalam 5 ulangan. Beberapa larva tidak ditemukan kembali saat pengamatan

${ }^{b}$ suspensi kontrol diencerkan pada konsentrasi $50 \mathrm{~mL} / \mathrm{l}$ (mewakili konsentrasi perlakuan tertinggi).

Insektisida sintetik memiliki efek yang cepat dalam mengendalikan serangga dibandingkan dengan formula insektisida nabati minyak bungkil mimba. Ferdian (2015) dalam penelitiannya menunjukkan bahwa insektisida sintesis pada konsentrasi $10 \mathrm{~mL} / 1$ mampu menyebabkan mortalitas hingga 56,67\% setelah 4 hari perlakuan, sehingga formula insektisida nabati dari minyak bungkil mimba dapat digunakan pertanian organik. Insektisida yang beredar secara luas di masyarakat merupakan hasil formulasi yang terdiri dari bahan aktif dan bahan tambahan (adjuvant). Keberadaan bahan tambahan sangat diperlukan karena memilki peranan penting dalam mekanisme kerja bahan aktif. Bahan tambahan yang digunakan dalam formulasi juga dapat menentukan bentuk formulasi insektisida.

\section{KESIMPULAN DAN SARAN}

\section{Kesimpulan}

Rasio terbaik antara minyak bungkil biji mimba dan n-heksan adalah 1:4 (b/v). Penentuan surfaktan DEA terbaik dengan metode critical micelle concentration (CMC) dalam minyak bungkil mimba didapatkan $8 \%$. Formulasi insektisida nabati yang mengandung surfaktan DEA $8 \%, 46 \%$ minyak bungkil biji mimba dan $46 \%$ solvesso dalam $30 \mathrm{~g}$ formulasi menghasilkan parameter tegangan permukaan $(38,85 \pm 0,64$ dyne/cm), sudut kontak $\left(12,74 \pm 0,37^{\circ}\right)$, dan ukuran droplet $(4,36 \pm 0,18 \mu \mathrm{m})$. Hasil uji formula insektisida nabati pada skala laboratorium dengan konsentrasi 10 dan $50 \mathrm{~mL} / 1$ pada 4 hari setelah perlakuan (HSP) mengalami mortalitas sebesar $4,2 \%$ dan $12,5 \%$.

\section{Saran}

Saran untuk penelitian ini adalah perlu dihilangkan pengotor pada minyak bungkil biji mimba setelah ekstraksi seperti gumdan senyawa pengotor lainnya.

\section{DAFTAR PUSTAKA}

Adisarwanto T. 2005. Strategi peningkatan produksi kedelai sebagai upaya untuk memenuhi kebutuhan di dalam negeri dan mengurangi impor. Pengembangan Inovasi Pertanian. 3(4): 319-331.

Al Hasan R, Jatoe JBD, dan Egyir IS. 2010. Biopesticides in Ghana : vegetable farmer's perception and willingness to pay. The IUP Journal of Agriculture Economics. 7 (4).

Athanassiou CG, Kontodimas DC, Kavallieratos NG, Veroniki MA. 2005. Insecticidal effect of NeemAzal against three stored-product beetle species on rye and oats. Journal Economic Entomology. 98: 1733-1738.

Blay E. 2000. Handbook of Crop Protection Recommendations in Ghana : An IPM Approach, Volume 2: Vegetables, Monistry of Food and Agriculture. Ghana.

Charlena, Mas'ud ZA, Syahreza A, Purwadayu AS. 2009. Solubility profile of petroleum waste in water as effect of nonionic surfactant and stirring rate. J Chem Prog. 2(2):69-78.

Dadang dan Prijono D. 2008. Insektisida Nabati, Prinsip, Pemanfaatan dan Pengembangannya. Bogor: Departemen Proteksi Tanaman, IPB.

De Man JM. 1997. Kimia Makanan. Kosasih Padmawinata, Penterjemah Bandung : ITB Pr. Terjemahan dari : Food Chemistry.

Ferdian MA. 2015. Kajian stabilitas emulsi produk insektisida hama wereng cokelat dengan penambahan surfaktan DEA dari metil ester olein sawit. [thesis]. Bogor: Institut Pertanian Bogor.

Hendrival L dan Hayu R. 2013. Perkembangan Spodoptera litura F. (Lepidoptera: Noctuidae) pada Kedelai. Jurnal Floratek. 8:88-100.

Houghton PJ dan Raman A. 1998. Laboratory Handbook for the Fractionation of Natural Extracts. London (GB): Chapman \& Hall.

Kardinan A. 2002. Pestisida Nabati: Ramuan dan Aplikasi. Jakarta: Penebar Swadaya.

Kavallieratos NG, Athanassiou CG, Saitanis CJ, Kontodimas DC, Roussos AN, Tsoutsa MS, Anastassopoulou UA. 2007. Effect of two azadirachtin formulations against adults of Sitophilus oryzae and Tribolium confusum on different grain commodities. Journal Food Protection. 70: 1627-1632.

Knowles A. 2008. Recent developments of safer formulations of agrochemicals. Journal Environment. 28:35-44.

Meidalima D. 2014. Perkembangan populasi ulat grayak (Spodoptera litura) pada kedelai di laboratorium. Jurnal Ilmiah Agriba. (2). 
[MSDS] Material Safety Data Sheet. 2012. Product Safety Summary. Solvesso 150 Fluid. ExxonMobil Chemical.

Packiam SM, Veeramuthu A, Savrimuthu I, Subramanian EV. 2012. Formulation of a novel phytopesticide PONNEEM and its potentiality to control generalist herbivorous lepidopteran insect pests, Spodoptera litura (Fabricius) and Helicoverpa armigera (Hübner) (Lepidoptera: Noctuidae). Asian Pacific Journal of Tropical Disease. 720723.

Probowati A, Paradigma CG, dan Diyono I. 2012. Pembuatan surfaktan dari minyak kelapa murni (VCO) melalui proses amidasi dengan katalis $\mathrm{NaOH}$. Teknologi Kimia dan Industri. 1(1) : 424-432.

Rukmana dan Yuyun. 2002. Nimba. Yogyakarta: Kanisius.
Schmutterer H. 1990. Properties and potential of natural pesticides from neem tree, Azadirachta Indica. Annual Review of Entomology. 35: 271-295.

Schoonhoven LM, Van Loon JJA, dan Dicke M. 2005. Insect Plant Biology. London (GB): Oxford University Press. Hal 101-116.

Sukrasno. 2003. Nimba Tanaman Obat Multifungsi. Jakarta: Agromedia Pustaka.

Suryani A, Dadang, Nisya FN, Nurkania A. 2012. Surfaktan berbasis minyak nabati untuk formulasi herbisida berbahan aktif glifosat. Laporan Penelitian. Bogor : SBRC LPPM IPB.

Yang Y, ME Leser, AA Sher, DJ McClements. 2013. Formation and stability of emulsions using a natural small molecule surfactant: Quillaja Saponin (Q-Naturale). Food Hydrocoll 30: 589-596. 